\title{
Indigenous legal tradition as a supplement to African transitional justice initiatives
}

\section{Daniel Mekonnen*}

\section{Abstract}

This article interrogates the role of indigenous legal tradition (ILT) in contemporary African transitional justice initiatives. It departs from the assumption that most African cultures put emphasis on communality and the interdependence of the members of a community. Indigenous legal traditions, which include mechanisms for acknowledgement, truth telling, accountability, healing and reparations, continue to assume a prominent role in the lives of African societies and individuals. However, little attention has been given to the role of African indigenous legal tradition in terms of its contribution to postconflict transformation. Several African societies have deeply rooted social and communal values of conflict resolution which can serve as a reservoir of wisdom in future transitional justice initiatives. In furtherance of the main theme,

* Dr Daniel Mekonnen, Dip Law (Asmara), LL.B. (Asmara), LL.M. (Stellenbosch), LL.D. (Free State), is Senior Visiting Researcher at the International Institute of Victimology (INTERVICT), Tilburg University, and has formerly been Judge of the Zoba Maekel Provincial Court, Eritrea. The author is grateful to Eva Brems and Martien Schotsmans for their invaluable comments. The institutional and financial support of the Human Rights Centre in Gent University and the Fonds Wetenschappelijk Onderzoek - Vlaanderen (Research Foundation - Flanders) is thankfully acknowledged. 


\section{Daniel Mekonnen}

the article discusses an example of ILT from Eritrea, and calls for a continued engagement and critical assessment of these values in promoting peace and justice in Africa.

\section{Introduction}

Several African countries suffer from previous cycles of conflict, and such conflict and post-conflict scenarios have been very common attributes of the African continent. Examples of ongoing conflicts or repressive regimes are more prevalent in Africa than in other continents. Embedded in complex processes of transformation are the most overwhelming challenges to African countries. One such challenge manifests itself in the form of transitional justice ${ }^{1}$ and deals with transformation options societies may adopt in a post-conflict or post-dictatorship scenario. Post-conflict societies face challenges of immense magnitude in their transitional period which include, inter alia, securing stability, achieving reconciliation, promoting justice and maintaining a smooth process of transformation.

The options of post-conflict justice vary depending upon the prerogatives of societies - the prevailing domestic, social, political and economic realities. That unconditional blanket amnesty is no longer acceptable has become a consensus between proponents and opponents of amnesty. The most controversial debate, however, remains the one about the choice between prosecution and amnesties administered by truth and reconciliation commissions (TRCs) (Schabas 2004:12). However, this does not mean that transitional justice is just a matter of either prosecutions or TRCs, as it covers a whole range of options. With the refinement of norms of international law, the development of international criminal tribunals and the first ever permanent International Criminal Court (ICC), criminal prosecution is assuming a central place in the toolbox of transitional justice. However, there are concerns that strict adherence to international criminal law may undermine the capacity of local and indigenous responses to

1 The article adopts the definition of transitional justice as 'the study of the choices made and the quality of justice rendered' when states transit from conflict or repression to democracy (Siegel 1998:433). 


\section{Indigenous legal tradition as a supplement to African transitional justice initiatives}

the complex transitional and transformative needs of a society emerging from a deeply divided past (Du Plessis and Coutsoudis 2005:337).

By their nature, prosecutions have a very limited role in fulfilling the diverse needs of post-conflict transitions. The challenges of massive atrocities cannot be addressed merely by retributive justice mechanisms. This is so because 'the gap between the formal existence of an international human rights regime and the implementation of its provisions on the ground is large across the globe' (Coleman 2003:ii). As a result, the issue of enforcement of human rights standards in a post-conflict scenario has continued to be one of the most contentious issues among transitional justice scholars. The assessment of such drawbacks necessitates consideration of other forms of accountability.

In spite of the radical move of international opinion towards prosecution, TRCs as innovative institutions are attracting a wide range of attention among transitional justice scholars. TRCs have emerged as popular mechanisms within the toolbox of transitional justice and their indispensable contribution towards security and justice is growing noticeably (Schabas 2004:12). However, scholars suggest that when imposed as imported institutions, TRCs may not always prove supportive in the context of the complex realities of societies emerging from an atrocious past (Shaw 2005:1-2). In this regard, indigenous legal tradition (ILT) $)^{2}$ as a major component of transitional justice is also regarded as growing in importance.

In an African context of transitional justice, the exigency is evident and some of the questions to be asked are: Is the role of ILT adequately recognised in contemporary African transitional justice initiatives? How could specific peculiarities of culture and tradition play a role in transforming post-conflict societies?3 ${ }^{3}$ Acknowledging the huge knowledge gap on the potential role of ILT in transitional justice, researchers are now giving this particular issue the attention it requires. The work to be done in this regard is still tremendous, and this paper

2 As will be seen later, ILT is understood in the current context as a legal tradition based on indigenous knowledge and belief systems of communities. The term is at times interchangeably used with customary law.

3 One latest contribution in this regard is Schotsmans 2009. 


\section{Daniel Mekonnen}

intends to contribute modestly to the ongoing debate. Taking as example some relevant aspects of ILT in Eritrea that could possibly inform any transitional justice efforts in the future, the paper argues in favour of promoting the role of ILT in African transitional justice initiatives. In so doing, it departs from the increasing call to make ILT only one form of transitional justice in Africa. Its main contribution to existing academic literature is that it sheds some light on aspects of ILT in Eritrea, a country which is hardly discussed in the context of transitional justice, ${ }^{4}$ in spite of the dire situation of human rights violations in the country. In so doing, the paper consolidates and develops further the analysis of ILT concisely presented in a previous work of this author (Mekonnen 2009:214, 236, 252). Although essentially a theoretical work, the paper also offers analysis of practice in some post-conflict societies based on ground level empirical research conducted in those societies by some transitional justice researchers.

\section{Conceptualising ILT}

A discussion on African ILT requires clarification on the parameters of reference and the framework of analysis. The starting point is African philosophy, the broader branches of which also incorporate cultural and legal aspects of the African society. Although the debate on the very meaning of African philosophy remains largely unsettled, Cornell and Van Marle suggest that there is some degree of awareness that allows ontological investigation into African indigenous knowledge systems (IKS). This has been pursued, according to the authors, through a genealogy of the social and historical origins of African IKS. This includes a genealogy of the anthropological methods used to articulate what the authors call, borrowing the description of Mudimbe, 'African gnosis' (Cornell and Van Marle 2005:197; Mudimbe 1988:186).5 This characterisation is true both at the theoretical and the practical level, which means that any investigation into IKS may also include the study of how African rituals, practices and social

4 For a general discussion of Eritrea as a forthcoming model of transitional justice, see Mekonnen 2009.

5 Cornell and Van Marle, citing Mudimbe, assert that gnosis 'means seeking to know, inquiry, methods of knowing, investigation, and even acquaintance with someone. The authors do not use IKS in their discussion of African philosophy. Instead, they use 'indigenous system', which in the context of their discussion is not different from IKS. 


\section{Indigenous legal tradition as a supplement to African transitional justice initiatives}

encounters are experienced within specific cultural contexts. Therefore, an investigation of African ILT in the current context may also mean an examination of one aspect of African IKS. According to Nel (2005:7):

IKS may be defined as a systemic reference to the knowledge and practices of indigenous communities constitutive of their meaning and belief systems, as well as the substantive dimension of their practices and customs. Accordingly, IKS is about the knowledge, practices, values and ways of knowing and sharing in terms of which communities have survived for centuries. IKS is not only the knowledge and practices of culture, custom, agriculture, medicine, bio-diversity, ethno-numeracy, customary law, and so on, but also the rationality of these cultural practices and rites that effected social cohesion, creativity and artistry of dance and music, technologies of fashioning clothing and beadwork, and, last but not least, of a diffused spirituality that unites cosmos and being in a holistic manner. ${ }^{6}$

As far as transitional justice discourse is concerned, IKS also encompasses a system of knowledge related to social and political structures of society, identities, legal practices and jurisprudence, traditional governance and decision processes, conflict resolution and other related concepts (USF 2007; Nel 2005:4-6, 9).7 In this regard, Emeagwali describes IKS as 'a source of healing of therapeutic import in the context of unhealthy imbalances' caused by continued cycles of injustice (Emeagwali 2003). Therefore, to make IKS responsive to contemporary African problems would mean to enhance the role of ILT in the context of transitional justice.

A most known aspect of African IKS is $u b u n t u$, which according to Cornell and Van Marle, is a fundamental African philosophy which appears in most African

6 See also the definition of IKS adopted by the University of the Free State (2007) according to which IKS was defined as the knowledge system distinctive from 'the international knowledge systems generated through universities, government research centres and private industry, sometimes incorrectly called the Western Knowledge System'.

7 Nel also discusses the role of IKS in post-conflict societies and the better alternatives IKS offer towards the realisation of a new humanity and civility. For further discussions of IKS in the context of African contemporary problems, see Castiano 2005:v. 


\section{Daniel Mekonnen}

languages either literally as 'ubuntu' or something very close to it. The underlying assumption of $u b u n t u$ is that 'individual rights cannot be meaningfully exercised in isolation of broader community rights' (Cornell and Van Marle 2005:220). There is no better example than the experience of South Africa in terms of the appropriate usage of ubuntu in a purely transitional justice context. In fact, this is one of the best lessons the South African model of transitional justice offers. As a typical traditional African concept denoting 'humanity to others' (Nabudere 2004:10), the role of ubuntu in the South African experience was explicitly recognised in the post-amble of the country's Interim Constitution which urged focus on the future, rather than on the past 'on the basis that there is a need for understanding, but not for vengeance, a need for reparation, but not for retaliation, a need for ubuntu but not for victimisation'. The concept is perhaps best illustrated by the following remarks of the South African Constitutional Court, as given in $S v$ Makwanyane and Another: ${ }^{8}$

The concept is of some relevance to the values we need to uphold. It is a culture which places some emphasis on communality and on the interdependence of the members of a community. It recognises a person's status as a human being, entitled to unconditional respect, dignity, value and acceptance from the members of the community such person happens to be part of. It also entails the converse, however. The person has a corresponding duty to give the same respect, dignity, value and acceptance to each member of the community. More importantly, it regulates the exercise of rights by the emphasis it lays on sharing and co-responsibility and the mutual enjoyment of rights by all.

81995 (3) SA 391 (CC), para 224. Similarly, Gibson (2002:543) quotes Tutu's words on ubuntu as follows: 'Ubuntu says I am human because you are human. If I undermine your humanity I dehumanise myself. You must do what you can to maintain this great harmony, which is perpetually undermined by resentment, anger, desire for vengeance. That's why African jurisprudence is restorative rather than retributive. However, the author notes that there are some critics who argue that in the context of some African transitional justice experiences, the use of $u b u n t u$ has been only superficial. 


\section{Indigenous legal tradition as a supplement to African transitional justice initiatives}

Long before the advent of transitional justice as a popular academic discourse, Cobbah (1987:320) has also articulated the rightful place of the concept of ubuntu in African ILTs and its relation with human rights as follows:

For the African, a philosophy of existence can be summed up as: 'I am because we are, and because we are therefore I am'. A comparison of African and Western social organisation clearly reveals the cohesiveness of African society and the importance of kinship to the African lifestyle. Whereas Westerners are able to carry out family life in the form of the nuclear family and often in isolation from other kin, Africans do not have the concept of a nuclear family and operate within a broader arena of the extended family.

Within the organisation of African social life one can discern various organising principles. As a people, Africans emphasise groupness, sameness, and commonality. Rather than the survival of the fittest and control over nature, the African worldview is tempered with the general guiding principle of the survival of the entire community and a sense of co-operation, interdependence, and collective responsibility.

The analysis of Cobbah is essentially based on the experience of the Akan community in Ghana. Nonetheless, there are corresponding similarities of the same value system in many African cultures. As a result of such an understanding, he concludes that most African cultures place emphasis on communality and on the interdependence of the members of a community. ILTs, which may also include mechanisms for acknowledgement, truth-telling, accountability, healing and reparation, continue to assume a prominent role in the lives of societies and individuals. This is a very important factor to consider when discussing transitional justice issues in an African context. In relation to the experience in Sierra Leone, for example, Shaw argues that a transitional justice approach which ignores the fundamental facets of societal values jeopardises social recovery (Shaw 2005:1-2; Shaw 2007; Mallinder 2007). Likewise, the former chairperson of the Historical Clarification Commission of Guatemala asserts that as outcomes of a deliberate policy of compromise or results of a stalemate in a political power play, transitional justice mechanisms must be crafted according to the specificities of 


\section{Daniel Mekonnen}

the national situation and the objectives of the particular country (Tomuschat 2001). This factor is inherently intermingled with due recognition that must be given to ILT. A foundational edifice based on purely foreign standards can seriously undermine the overall effort of transitional justice. In this regard, particular attention must be paid to ideas concerning the conciliatory and therapeutic efficacy of truth-telling as weighted against established societal values (Shaw 2005:2). Having said the above about the conceptual framework of African ILT, we will now consider the relationship between restorative justice and ILT.

\section{Restorative justice as an essential element of ILT}

As noted above, ubuntu represents one crucial aspect of African philosophy and legal theory. According to Cornell and Van Marle, its underlying assumption denotes an interactive ethic by which humanity is essentially defined by the interaction of community members towards each other. This represents an 'understanding that our humanness is shaped in our interactions with one another and within a force field created and sustained by those interactions' (Cornell and Van Marle 2005:322). Thus, the pursuit of human dignity in the African philosophy is more concerned with vindication of the communal wellbeing and restoration of broken relationships rather than with the right of any individual against the world (Cobbah 1987:322). The humanist and collective emphasis in ubuntu, argue Cornell and Van Marle (2005:220), has striking similarities with the theory of restorative justice. In fact, Gilman asserts that restorative justice has its roots in community origins and its theoretical foundation is deeply rooted in many ancient cultures (Gilman 2008). ${ }^{9}$ In elaborating this, Tutu, as cited by Minow (1998:81), opines:

9 Similarly, the Centre for Restorative Justice (2008) holds that 'restorative justice is an old idea with a new name' and 'its roots can be found in [communal] healing traditions and the non-retaliatory responses to violence endorsed by many faith communities' as well as in social, theological and philosophical movements. Accordingly, restorative justice strives 'to embody the values and principles that are akin to and informed by holistic peace and justice-making processes in many ... communities'. 


\section{Indigenous legal tradition as a supplement to African transitional justice initiatives}

The African understanding is far more restorative - not so much to punish as to redress or restore a balance that has been knocked askew. The justice we hope for is restorative of the dignity of the people.

McEvoy and Eriksson explain the central element of restorative justice as the facilitation of dialogue and reconciliation among victims, offenders, and community. The goals of restorative justice are also explained as something which includes: 'the acceptance of responsibility by offenders, reparation of harm, strengthening the connections of victims and offenders to their community, and the promotion of more stable and peaceful communities' (McEvoy and Eriksson 2006:321).10 Furthermore, quoting Dignan (1999:2), Findlay and Henham (2005:xxii) suggest that the philosophy upon which restorative justice is based can best be summarised in terms of three principles:

Responsibility - to engage with offenders to try to bring home the consequences of their actions and an appreciation of the impact they have had on the victim(s) of their offences.

Restoration - to encourage and facilitate the provision of appropriate forms of reparation by offenders towards either their direct victims ... or the wider community.

Reintegration - to seek reconciliation between victim and offender where this can be achieved and, even in cases where this is not possible, to strive to reintegrate both victims and offenders within the community as a whole following the commission of an offence. ${ }^{11}$

10 See also the definition of local justice offered by Waldorf (2006:9-10), which has striking similarities with the essential elements of restorative justice discussed in the current debate. According to Waldorf, the essential elements of local justice are: focus on groups rather than on individuals; compromise and community harmony; emphasis on restitution over other forms of sanctioning; accessibility and informality of procedures; and public participation.

11 Compare this with the five key points of restorative justice developed by Gilman (2008). One of the observations of Gilman is that: 'Active community participation is essential to creating safe and healthy communities. The community as a whole, not the justice system in isolation, has the ability and resources to effectively respond to the harms of crime and to ultimately restore victims and integrate offenders into the community as healthy, whole contributing members of society'. 


\section{Daniel Mekonnen}

The authors further contend that the underlying rationale for restorative justice focuses on the establishment of truth rather than individual liability. Envisaged as a transformative mechanism, restorative justice links together notions of morality, law and behaviour around the pursuit of 'truth'. This purposive social function resonates with the universal appeal for constructive engagement, a formulation also supported by Gilman (2008), one of the most articulate proponents of restorative justice (Findlay and Henham 2005:xv, xxiii, xxiv). Gilman (2008) argues that restorative justice has a future focus, a focus on outcomes with three key groups who must meaningfully add their respective contribution to the reparation of harm. These groups are: the direct victims, the wider, impacted community and the offender (Gilman 2008). ${ }^{12}$

Based on the experience of Northern Ireland, McEvoy and Eriksson highlight that the needs of political transition, such as reintegration and reconstruction, strongly resonate with the objectives of restorative justice. Indeed, central to the broader objectives of transitional justice is societal healing and recovery at a national level, something intrinsic to the theory of restorative justice. One of the possible ways by which restorative justice can be applied in the context of political transition is through community-based processes of healing and reconciliation (McEvoy and Eriksson 2006:321). When there are well established value systems of restorative justice the challenge could be less demanding. It is believed that African ILT provides readily available value systems of restorative justice whose contribution to transitional justice is the subject of ongoing debate. It is true that in most cases these value systems remain untested in the context of transitional justice. However, they provide a reservoir of wisdom which can serve as a good

12 Gilman (2008) further argues that outcomes for victims should focus on: 'being given the opportunity to be acknowledged and heard; having input regarding resolution to the offence; having the harms done to them meaningfully addressed; meaningful support services for healing and closure'. Outcomes for the community should focus on: 'creating safe and healthy communities; active and extensive partnerships with the justice system that lead to the integration of victims and offenders into the community as positive, contributing members'. And lastly, outcomes for offenders should focus on: 'being accountable for the harms done; taking an active role in determining how to make amends to victims and the community; integration into the community as positive and productive citizens'. 


\section{Indigenous legal tradition as a supplement to African transitional justice initiatives}

source in future transitional justice initiatives. The following example from Eritrea, although not yet tested in a transitional justice context, is illustrative.

Up to this date, the most important source of law relevant to restorative justice in Eritrea is ILT. The basis of law in much of rural Eritrea, which constitutes $80 \%$ of the total population, remains customary law. Eritrean customary laws are greatly influenced by deeply rooted communal values and as such restorative justice is a central element in that system.

In a typical Eritrean highland legal tradition, one way by which restorative justice manifests itself is in the case of homicide. In such cases, the customary laws focus on the victim of the crime. Restitution and reconciliation are important factors as they are considered crucial in restoring the harm done to a victim. Regularly, a transgression involving homicide is resolved by the payment of blood money, called gar nebsi (. $\boldsymbol{M}$ ?nn.), by the wrongdoer to the family or relatives of the deceased (Russell 1958:103). Gar nebsi can be paid in the form of money, cattle or other items, or a combination of all. In such cases, the kinship of the wrongdoer takes collective responsibility and restores the harm done to the victim accordingly. Intermarriage between family members or relatives of the wronged and the wrongdoer is also an important and common practice in dispute resolution mechanisms involving homicide. Although a rare practice, the family or relatives of the deceased may at times unilaterally resort to a vengeful retaliatory act which includes the killing of any close member of the wrongdoer's family or relatives. A pertinent example of an indigenous healing and reconciliation ritual can be observed from the following provision of the customary law of Adkeme Mlgha'e:

One who kills shall stand and submit himself in front of the family of the deceased, and shall say 'finish me', holding a knife, wearing unworthy garments and with a rope on his neck. Afterwards, seven elders and priests with their cross shall ask for forgiveness. Firstly, his soul shall be forgiven, and then shall follow reconciliation. Guarantors shall secure the reconciliation. When reconciliation is done, the wrongdoer shall pay blood money. The blood money shall be paid on an agreed date. If the blood money is to be paid in the form of land, the elders shall oversee the implementation. If the family of the wrongdoer and the wronged are not related, they shall then 


\section{Daniel Mekonnen}

give each other a boy and a girl. Those who shall give a girl are the family of the wrongdoer. ${ }^{13}$

A striking element is that imprisonment is not seen as an option. In fact, there are no clearly defined rules in the Eritrean customary laws prescribing imprisonment or criminal punishment as a punitive method, even in the case of serious offences such as murder. There are some vague references in Chapters 8 and 9 of the customary law of Loggo Chiwa about punitive measures that could be taken by a king in the case of murder. ${ }^{14}$ However, these are not sufficient enough to be regarded as providing for criminal punishment in the modern sense of the concept.

The concept of restorative justice is also deeply ingrained in several proverbial expressions of the Tigrinya language, a major vernacular in the Eritrean highlands with a de facto official status since Eritrea's independence in 1991. Tigrinya proverbial expressions are apparent reflections of the Eritrean highland customary laws. The nearly comprehensive work of Liqe Mezemran Moges Ouqbegiorgis (1969) on Tigrinya maxims offers pertinent examples of proverbial expressions with deeply rooted conceptions of restorative justice. The following samples are most instructive. ${ }^{15}$

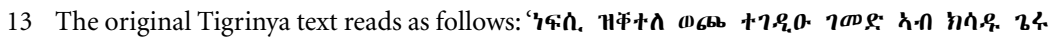

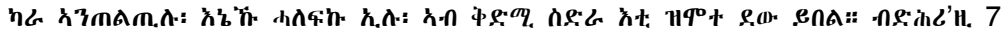
त̆

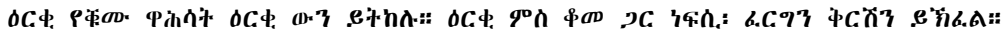

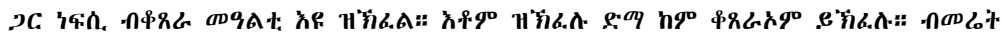

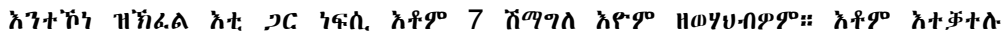

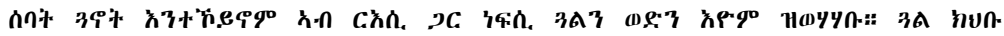

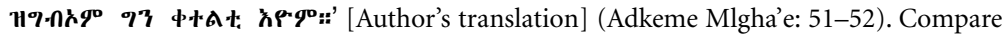
this with the Ugandan traditional healing mechanisms of mato oput, nyouo tong gweno and gomo tong as discussed by Quinn (2006:398). However, the Eritrean proverb tends to discriminate on the basis of gender.

14 Examples of other provisions dealing with murder are Chapter 13 of the customary law of

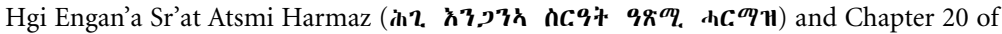
the customary of law of Adghena Tegheleba.

15 Compare these proverbial expressions with the customary law of the Thembu people in Eastern Cape, South Africa, as discussed by Kgosimore (2002:71). The author argues that Thembu people 'attain justice through practicing a philosophy of healing and reconciliation by placing the victim, the offender and the community at the heart of the justice'. See also Nsereko (1992:21). 


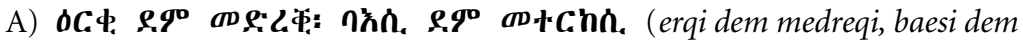
meterkesi): Reconciliation cures a wound, retribution fuels a dispute.

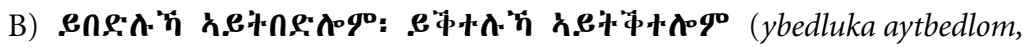
yqteluka aytqtelom): It is better to be harmed than to do harm to others.

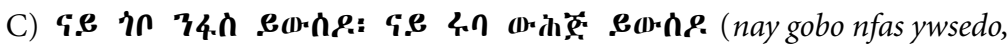
nay ruba whj ywsedo): That which is on the mountain should be gone with the wind and that which is in the riverbed should be washed away by the waters.

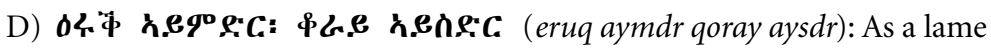
cannot walk, a reconciled cannot also squabble. This proverb has, however, an apparent bias against people with a disability.

These and other important aspects of ILT were oppressed during colonialism by a European worldview of retributive justice which is largely offender focused. ${ }^{16}$ In the post-independence era, little has been done to advance their usefulness in human rights protection and post-conflict reconstruction. In this regard a golden opportunity was missed in the period between 1991 and 1993 when the provisional government failed to adopt a comprehensive transitional justice agenda fitting to post-independence challenges of the country (Mekonnen 2009:51). As a potential reservoir of wisdom, the heritage of ILT is not yet fully appreciated and explored in Eritrea.

It is evident that the four essential elements of transitional justice, namely truth, accountability, reparation and reconciliation, ${ }^{17}$ also make the epicentre of most

16 Eritrea inherited all of its codes of laws from Ethiopia in 1991, with minor amendments. The Ethiopian Penal Code of 1957, which is drafted by the Swiss jurist, Jean Graven, is one good example. The Ethiopian Codes of Criminal Procedure and Civil Procedure are also drafted by the same jurist, while the 1960 Ethiopian Civil Code is drafted by the French jurist, René David. See Russell (1961). All of the above codes together with the Ethiopian Commercial Code and Maritime Code were adopted by Eritrea in 1991 as transitional codes and are still operational, albeit ineffectively as far as the protection of human rights is concerned.

17 See for example, Parmentier's (2003:207-208) TARR, an acronymic-innovative model on the four essential issues of transitional justice which denotes: truth, accountability, reconciliation, and reparation. See also Huyse (2008:11); Vandeginste (2009:25). 


\section{Daniel Mekonnen}

ILTs. For example, in the Eritrean customary law of Adkeme Mlgha'e, both truth and accountability are embedded in the relevant provision of the law by the fact that the law obliges the wrongdoer to 'stand and submit himself in front of the family of the deceased', to an extent that the wrongdoer is even required to metaphorically plead the family of the victim to 'finish him off'. This is one clear example of ILT that represents established local values and traditions which are better suited 'to creating a collective atmosphere that opens the heart and the mind' and deliver the truth about the past (Huyse 2008:187). If explored purposefully, these values can have the potential of restoring broken community relations and damaged social capital.

Truth-telling and accountability in the customary law of Adkeme Mlgha'e are supplemented by an official request for forgiveness that should be submitted not by the wrongdoer but rather by his representatives who shall be seven elders and priests with their cross. This denotes at the same time a deeply rooted practice and symbolic ritual of reconciliation, which is the third important element of transitional justice. The fourth key issue of transitional justice, reparation, could be done in the form of payment of blood money but it can also be implemented by intermarriage between the families of the victim and the wrongdoer. This way, the law essentially captures four of the essential elements of transitional justice, as represented in Parmentier's (2003:207-2008) innovative model of TARR (truth, accountability, reparation and reconciliation). The example from Eritrea shows that restorative justice is a very essential element of ILT in Africa.

\section{When does ILT play a role?}

It must be noted that ILT may not be taken as a complete replacement to formal transitional justice approaches such as TRCs. The role of ILT, as discussed in this work, is recognised mainly as a complementary one. In most cases formal transitional justice mechanisms such as TRCs operate during the first few years after a conflict has come to an end. Reflecting on her fieldwork in Sierra Leone, Schotsmans notes that the initial period of transition is usually characterised by a high level of uncertainty on the part of witnesses or victims who often seem to be reluctant to publicly testify about what happened in the past. However, with the mere lapse of time and the consolidation of democratic transition, 


\section{Indigenous legal tradition as a supplement to African transitional justice initiatives}

people may feel more secure and are naturally encouraged to publicly share their experiences about the past. By this time, a TRC may have already closed its offices and compiled its final report. Yet, the need for truth-telling, healing and social recovery may stand as a crucial element in the transitional process. At such a time, what could have not been accomplished by TRCs or other formal transitional justice mechanisms can be supplemented by traditional truth-telling and reconciliation mechanisms. Therefore, the major role of ILT would be that of filling up any gaps that have not been filled by formal justice mechanisms (Schotsmans 2009).

Apart from accomplishing whatever objectives that have not been attained by formal justice mechanisms, the usefulness of ILT is evident from the following advantages discussed by Ingelaere. According to him, the strength of traditional justice mechanisms lies in the fact that they function in line with the sociocultural habitat of the population in their daily activities (Ingelaere 2008:53). At community level, perceptions about classical justice mechanisms, particularly criminal prosecutions, portray such initiatives as Western ways of doing justice. This view is evident in the Rwandan experience which perceives the International Criminal Tribunal for Rwanda (ICTR) as 'highly inefficient, time-consuming, expensive, and not adapted to Rwandan custom' (Ingelaere 2008:45). While the role of criminal prosecutions in ensuring accountability is beyond contention, pervasive perceptions that revolve around such initiatives are also equally important in terms of long-term objectives of healing and social recovery. These perceptions point to a certain degree of a transitional justice gap that must be filled by other subsidiary or complementary methods. In this regard, the efficacy of home-grown traditions derived from the socio-cultural fabric of conflict-torn communities needs to be assessed against the usefulness of imported practices which are at times seen as alien impositions (Ingelaere 2008:32).

A strategy based on ILT also enhances the capacity of local communities to take ownership over justice initiatives and to develop the required self-confidence for partnership with the state apparatus which is widely seen as oppressive machinery given a violent past that divides societies across several lines (McEvoy and Eriksson 2006:322). As argued earlier, the basis of ILT is restorative justice which helps in building a strong sense of grassroots community ownership. 


\section{Daniel Mekonnen}

After violent conflict, there is a great deal of scepticism towards the entire state apparatus because of the fact that in almost all cases state organs are the leading role players in the perpetration of atrocities. As a result, the role of a state in a post-conflict scenario cannot be easily divorced from its role in the violent past. In such a context, it is argued:

[I]t makes sense that communities themselves should take primary ownership over the establishment of programmes, deciding what type of intervention might be suitable, who is going to be involved, which values will guide their work and devise their own benchmarks as part of a broader 'legitimation process'. Those with the greatest stake in justice reconstruction - often those who have been on the receiving end of violence and criminality ... should themselves be direct participants in the process as innovators, planners and implementers. Community participation in decision-making processes regarding the rebuilding of a society adds transparency, accountability, legitimacy, and, importantly minimises the risk of renewed conflict. Top-down initiatives need to be accompanied by culturally appropriate grassroots programmes ... (McEvoy and Eriksson 2006:322-323).

The above argument derives from an understanding of the authors that community-based restorative justice programmes are uniquely suited for embedding a bottom-up culture of human rights. In many transitional justice initiatives, experience has shown that top-down approaches to conflict resolution are often not enough to resolve deeply entrenched legacies of a violent past. Transparent, inclusive and consensual practices of restorative justice are catalyst factors for the empowerment of local communities and the promotion of grassroots ownership of justice. Such approaches can 'add legitimacy to a vital transformation of deeply ingrained cultures of violence, which in turn reduces the risk of renewed conflict' (McEvoy and Eriksson 2006:331-332). By mainstreaming the transformation process beyond the confines of state structures, a deep sense of ownership can be created among the communities which are most affected by violations. This kind of 'sensible and sensitive approach to local circumstances' promotes grassroots human rights entrenchment, an essential template for 
societies in transition. The ultimate end result would be transforming cultures of violence with robust actions at the grassroots level as opposed to a narrowly defined objective of ensuring individual criminal liability of offenders (McEvoy and Eriksson 2006:331-332).

As noted by Vandeginste, the debate on the efficacy of ILT in transitional justice initiatives is part of the growing concern 'about the local relevance of the increasingly globalised transitional justice field' (Vandeginste 2009:365). One such concern is expressed by Orentlicher (2007:18) who advises that 'there cannot be a one-size fits-all approach to transitional justice'. Simply put, in the face of an 'extraordinary range of national experiences and cultures' it is difficult to imagine the adoption of a universally relevant transitional justice formula. In this regard, Orentlicher is availing herself of a critical retrospection on some essential transitional justice elements she provided earlier in one of her influential contributions (Orentlicher 1991). Her retrospection calls for the expansion of the scope of the local variation in responding to past atrocities. Local in this sense may also mean traditional justice, as analogised by Waldorf (2006:9). There is indeed a growing need for local agency and the involvement of local communities in transitional justice initiatives. In this regard, exploring the potential of home-grown justice mechanisms as tools of social reconstruction means nothing more than localising transitional justice (Vandeginste 2009:366).

\section{Limitations of ILT}

There are, however, some inherent shortcomings of ILT that require attention for improvement. Informal conflict resolution mechanisms may require some degree of reform in order to make them more responsive to contemporary needs, particularly in the context of mass political atrocities. For example, in reference to the much debated ILT of Uganda, the mato oput, Rose and Ssekandi (2007:110) argue that this particular institution was not purposefully intended for mass political atrocities such as rape and wanton killing committed in armed conflicts. This calls for an adaptation of the institutions of ILT in the context of current needs. Similar concerns are raised by Huyse who argues that the efficacy of ILT would be less meaningful without the required reform that should make these institutions responsive to contemporary challenges (Huyse 2008:185). The 


\section{Daniel Mekonnen}

reform agenda can best serve its purposes if the limitations of restorative justice are supplemented by principles of distributive justice which are also deemed by many as more relevant in African societies.

Reform may also include the inclusion of women and younger people in the processes (Ingelaere 2008:48-49; Schotsmans 2009). However, as seen in the Rwandan experience, excessive interference in the structure and modus operandi of informal justice mechanisms may entail the risk of diluting the essence of such mechanisms. The commonest characteristic feature of traditional justice mechanisms is the restoration of harmonious relations by way of mostly symbolic and restorative measures that take the form of reparation for harm rather than punishment of offenders. With excessive government interference, this essential purpose might be replaced by a purely retributive impulse, thereby countering the fundamental edifice of traditional justice conceptions. Formalised justice may require a narrow legalistic approach, while traditional justice needs a culturally sensitive approach (Ingelaere 2008:53). As noted by Ingelaere (2008:51), this vital ingredient was not essentially captured in the new version of the gacaca courts of post-genocide Rwanda, which are different from the old gacaca courts in the sense that the new gacaca courts are state-sanctioned bodies in contrast to the tradition-sanctioned old gacaca courts.

As noted before, some archaic remedies of ILT may not be easily applicable in every transitional justice context. However, as much as possible from the process and rituals need to be incorporated into transitional justice initiatives in order to give symbolic effect to the underlying notion of restorative justice. One of the possible ways by which this can be done is in the public hearing of TRCs. Public hearings are important ingredients in the operation of TRCs as they are meant to advance national or community healing and reconciliation (Minow 1998: 71-72; Quinn and Freeman 2003:1145-1146; Buergenthal 1994:292, 321; OHCHR 2006:31). In order for the indigenous context to play a catalyst role, the modus operandi of TRCs could be designed in such a way that traditional leaders, elders and experts of customary laws are allowed to take part in the public hearings of TRCs. To allow this, public hearings could be organised at the local level, including villages and smaller communities, where deeply rooted indigenous healing and cleansing mechanisms can be utilised effectively. Another possibility 
is the establishment of a council of traditional leaders and elders representing important aspects of ILT allowing them to serve with an advisory role to a given TRC. Some traditional leaders can also be nominated to serve in subcommittees of TRCs on a representative basis. This may help in introducing innovative indigenous approaches that enable societies to heal their wounds via long held traditions of dispute resolution and healing mechanisms. Schotmans advises that with the support of NGOs and donor funding, monitoring and evaluation mechanisms as well as guarantees or oversight mechanisms against abuses by traditional leaders can also be put in place effectively (Schotsmans 2009).

\section{Conclusion}

Processes of transformation involve many and diverse challenges due to the very precarious nature of transitions. In the African continent, where guns have continued to usurp the place of reason, transitional justice and transformation issues are some of the prominent preoccupations of the continent's policy makers and researchers. Apart from formal transitional justice mechanisms, such as prosecutions and TRCs, ILT as a major component of transitional justice is receiving growing importance among researchers and scholars. As a system of knowledge related to social and political structures of society, identities, legal practices and jurisprudence, traditional governance and decision processes, conflict resolution and other related concepts, ILT assumes a prominent role in the daily actions and interactions of African societies.

In those societies, ILT is seen as the most catalytic factor in dealing with the past and restructuring broken relationships. Most African cultures place emphasis on communality and on the interdependence of the members of a community. ILTs, which may also include mechanisms for acknowledgement, truth-telling, accountability, healing and reparation, continue to assume a prominent role in the lives of societies and individuals. With its strong emphasis on restorative justice, ILT aims at the pursuit of human dignity via vindication of the communal wellbeing and restoration of broken relationships rather than the right of any individual against the world. As such, ILT reinforces the four essential elements of transitional justice, namely truth, accountability, reparation and reconciliation. However, it is important to note that ILT may not be taken as 


\section{Daniel Mekonnen}

a complete replacement to formal transitional justice approaches such as TRCs. The role of ILT is recognised mainly as a complementary one. There are also some inherent shortcomings of ILT that require attention for improvement. Informal conflict resolution mechanisms may require some degree of reform in order to make them more responsive to contemporary needs, particularly in the context of mass political atrocities. The contribution of ILT may be best utilised through its incorporation in the public hearings of TRCs.

\section{Sources}

Buergenthal, Thomas 1994. United Nations Truth Commission for El Salvador. Vanderbilt Journal of Transnational Law, 27.

Castiano, José P. 2005. Can indigenous knowledge provide solutions to current problems? African Journal of Indigenous Knowledge Systems, 4 (2).

Centre for Restorative Justice 2008. Introduction to restorative justice. Available from: $<\mathrm{http}: / /$ www.sfu.ca/crj/popular.html\#intro> [Accessed 2 April 2008].

Cobbah, James A.M. 1987. African values and the human rights debate: An African perspective. Human Rights Quarterly, 9.

Coleman, William D. 2003. Preface. In: Quinn, Joanna. Acknowledgement: The way to forgiveness. Institute on Globalization and the Human Condition, Working Paper Series.

Cornell, Drucilla and Karin van Marle 2005. Exploring ubuntu: Tentative reflections. Africa Human Rights Law Journal, (5).

Constitution of the Republic of South Africa (Interim), Act 200 of 1993.

Dignan, James 1999. Restorative crimes prevention in theory and practice. Prison Service Journal, 123.

Du Plessis, Max and Andreas Coutsoudis 2005. Serious human rights violations in Zimbabwe: Of international crimes, immunities, and the possibility of prosecutions. South African Journal on Human Rights, 21.

Emeagwali, Gloria 2003. African Indigenous Knowledge Systems (AIK): Implications for the curriculum. In: Falola, Toyin. ed. Ghana in Africa and the world: Essays in Honor of Adu Boahen. Trenton, Africa World Press, also available http://www.africahistory.net/AIK.htm.

Findlay, Mark and Ralph Henham 2005. Transforming international criminal justice: Retributive and restorative justice in the trial process. Devon, Willan Publishing.

Gibson, James M. 2002. Truth, justice and reconciliation: Judging the fairness of amnesty in South Africa. American Journal of Political Science, 46.

Gilman, Eric 2008. What is restorative justice? Available from: $<$ http://www.sfu.ca/cfrj/fulltext/ gilman.pdf $>$ [Accessed 2 April 2008].

Huyse, Luc 2008. Introduction: Tradition-based approaches in peacemaking, transitional justice and reconciliation policies. In: Huyse, Luc and Mark Salter. ed. Traditional justice 


\section{Indigenous legal tradition as a supplement to African transitional justice initiatives}

and reconciliation after violent conflict: Learning from African experiences. Stockholm, International IDEA (International Institute for Democracy and Electoral Assistance).

Ingelaere, Bert 2008. The Gacaca courts in Rwanda. In Huyse, Luc and Mark Salter. ed. Traditional justice and reconciliation after violent conflict: Learning from African experiences. Stockholm: International IDEA.

Kgosimore, David 2002. Restorative justice as alternative way of dealing with crime. Acta Criminologica, 15 (2).

Mallinder, Louise 2007. Can amnesties and international justice be reconciled? International Journal of Transitional Justice, 1 (2).

McEvoy, Kieran and Anna Eriksson 2006. Restorative justice in transition: Ownership, leadership and 'bottom-up' human rights. In: Sullivan, Dennis and Larry Tifft eds. Handbook of restorative justice. Devon, Willan Publishing.

Mekonnen, Daniel 2009. Transitional justice: Framing a model for Eritrea. Saarbrucken, VDM Publishing.

Minow, Matha 1998. Between vengeance and forgiveness: Facing history after genocide and mass violence. Boston, Beacon Press.

Mudimbe, Valentine Y. 1988. The invention of Africa: Gnosis, philosophy, and the order of knowledge. Bloomington, Indiana University Press.

Nabudere, Dani W. 2004. Ubuntu. In: Villa-Vicencio, C. and E. Doxtader eds. Pieces of the puzzle: Key words on reconciliation and transitional justice. Cape Town, Institute for Justice and Reconciliation.

Nel, Philip J. 2005. Indigenous Knowledge Systems: Contestation, rhetorics and space. African Journal of Indigenous Knowledge Systems, 4 (1).

Nsereko, Ntanda 1992. Victims of crimes and their rights. In Mushanga, T.M. ed. Criminology in Africa. Rome, UNICRI.

OHCHR (Office of the High Commissioner for Human Rights) 2006. Rule-of-law tools for postconflict states: Truth Commissions. Geneva, United Nations.

Orentlicher, Dianne 1991. Settling accounts: The duty to prosecute human rights violations of a prior regime. Yale Law Journal, 100.

Orentlicher, Dianne 2007. 'Settling accounts' revisited: Reconciling global norms with local agency. International Journal of Transitional Justice, 1 (1).

Ouqbegiorgis, Liqe Mezemran Moges 1969. Ancient proverbs of the forefathers. 2nd edition.

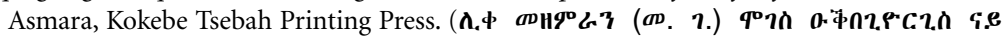

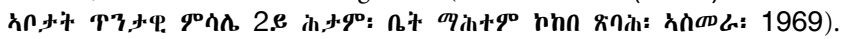

Parmentier, Stephan 2003. Global justice in the aftermath of mass violence: The role of the International Criminal Court in dealing with political crimes. International Annals of Criminology, 40 (1-2).

Quinn, Joanna 2006. Social reconstruction in Uganda: The role of customary mechanisms in transitional justice. Human Rights Review, 8(4). 


\section{Daniel Mekonnen}

Quinn, Joanna and Mark Freeman 2003. Lessons learned: Practical lessons gleaned from inside the truth commissions of Guatemala and South Africa. Human Rights Quarterly, 25.

Rose, Cecily and Francis M. Ssekandi 2007. The pursuit of transitional justice and African traditional values: A clash of civilizations - The case of Uganda. Sur - International Journal on Human Rights, 4 (7).

Russell, Franklin 1958. Eritrean customary law. Journal of African Law, 3 (2).

Russell, Franklin 1961. The new Ethiopian penal code. American Journal of Comparative Law, $10(3)$.

Schabas, William A. 2004. Introduction. In: Schabas, William A. and Shane Darcy eds. Truth commissions and courts: The tension between criminal justice and the search for truth. The Hague, Kluwer Academic Publishers.

Schotsmans, Martien 2006. The transitional justice gap in Sierra Leone: Is there a need to fill it and can tradition-based justice do the job? Paper presented at the International Conference on Taking Stock of Transitional Justice, Oxford Transitional Justice Research, Oxford University, 26-28 June 2009.

Shaw, Rosalind 2005. Rethinking truth and reconciliation commissions: Lessons from Sierra Leone. United States Institute of Peace, Special Report 130, February 2005.

Shaw, Rosalind 2007. Memory frictions: Localizing the truth and reconciliation commission in Sierra Leone. International Journal of Transitional Justice, 1 (2).

Siegel, Richard 1998. Transitional justice: A decade of debate and experience. Human Rights Quarterly, 20 (2).

Tomuschat, Christian 2001. Clarification Commission in Guatemala. Human Rights Quarterly, 20.

UNSG (United Nations Secretary-General) 2004. Report of the UN Secretary General on the Rule of Law and Transitional Justice in Conflict and Post-Conflict Societies, UN Doc S/2004/616/2004.

University of the Free State (UFS) 2007. Transformation in highly diverse societies: Concept paper on strategic cluster 3. Available from: <http://www.uv.ac.za/faculties/documents/01/ Kluster3-proposal-Sept_1.doc> [Accessed 10 October 2008].

Vandeginste, Steph 2009. Law as a source and instrument of transitional justice in Burundi. Leuven, University Leuven.

Waldorf, Lars 2006. Mass justice for mass atrocity: Rethinking local justice as transitional justice. Temple Law Review, 79 (1). 